\title{
Pecking-Order or Static Trade-off Theory in Family Firms? Evidence from Belgium
}

\author{
Jonathan Bauweraerts ${ }^{1} \&$ Olivier Colot $^{1}$ \\ ${ }^{1}$ Warocqué School of Business and Economics, University of Mons, Belgium \\ Correspondence: Jonathan Bauweraerts, University of Mons, Belgium. E-mail: \\ jonathan.bauweraerts@umons.ac.be \& Olivier Colot, University of Mons, Belgium. E-mail: \\ olivier.colot@umons.ac.be
}

Received: August 13, 2012

Accepted: September 12, 2012

Online Published: October 16, 2012

doi:10.5539/ibr.v5n11p1

URL: http://dx.doi.org/10.5539/ibr.v5n11p1

\begin{abstract}
The purpose of this paper is to investigate whether a difference can be stated in the family firms' financial choices. Using the Shyam-Sunder and Myers model, our research focus on the financial behaviour of family and non-family privately held firms in Belgium. Out of a sample of 210 privately held firms for the period 2002-2010, panel data methodology is employed to estimate Pecking-Order and Static Trade-off models. Our results show that although neither Pecking Order nor Static Trade-off Theory seems to apply to non-family firms, family firms are more likely to adopt an indebtedness target ratio. Moreover, the introduction of an allowance for corporate equity on the Belgian market is also taken into account. Our results indicate that such a mechanism seems to have an influence on the family firms funding choices.
\end{abstract}

Keywords: family firm, debt, financial structure, capital structure, financial behavior, allowance for corporate equity

\section{Introduction}

In the literature relative to the financial structure of the firm, two theories are regularly confronted. The theory of Modigliani and Miller (1958) revealed the neutrality of the financial structure under the hypothesis of a perfect market. By introducing corporate income tax, Modigliani and Miller (1963) demonstrated the superiority of firms using debts, since the take advantage of the deductibility of interest expenses. Nevertheless, this model was criticized because it did not take into account the costs of distress within the firm. In order to fill this gap, Static Trade-off Theory was built to develop a model based on a costs-profits analysis resulting from the issuance of debt (Krauss \& Litzenberger, 1973). This theory assumes the existence of a target indebtedness ratio equalling the profits of the deductibility of interest expenses and the costs of distress of the firm. Besides, an alternative theory was proposed by Myers and Majluf (1984): the Pecking-Order Theory. Under this theory, due to information asymmetry between managers and external investors, self-financing would be preferred to debts and stocks issuance by the managers.

More recently, many researches have tried to validate these theories empirically. The model proposed by Shyam-Sunder and Myers (1999) gives the opportunity to test for both Pecking-Order and Static Trade-off theories. In their research, they showed that Pecking-Order Theory would explain the financial structure of the firms. However, Frank and Goyal (2003) revealed that large U.S. public firms follow the Pecking-Order Theory while small firms violate this theory. Moreover, Famaand French (2005) showed that the Pecking-Order Theory could not explain the financial behaviour of more than the half of the sampled firms.

Despite the large proportion of family firms in the economy (Ifera, 2003; McCann, Demoss, Dascher \& Barnett, 2003; Duh, Tominc \& Rebernik, 2009), the financial behaviour of these organisations has received little attention. Even if the components of the financial structure have been identified to clarify their financing methods (Gallo \& Vilaseca, 1996; Colot \& Croquet, 2007), few studies have analysed the subject using a comparative methodology (Lopez-Gracia \& Sanchez-Andujar, 2007). However, such characteristics of family firms as risk aversion (Gallo \& Vilaseca, 1996; DeAngelo \& DeAngelo, 2000), the willingness to transmit the business (Colot, 2010) and the preservation of family control (Hirigoyen, 1982; Kenyon-Rouvinez \& Ward, 2004) have an influence on their financial behaviour. Hence, the main purpose of this paper will be to check if family firms develop specific types of financial behaviour compared to non-family firms. 
This paper will use the comparative model developed by Shyam-Sunder and Myers (1999). The confrontation of Pecking Order Theory and the Static Trade-off Theory will be tested on a panel data set collected over the period 2002-2010 for 210 firms in the Belgian market. Multiple linear regressions will make it possible to find evidence of different types of financial behaviour between family and non-family firms. Furthermore, we will take into account the setting up of a new tax regulation launched in 2006 by subsampling in two periods from 2002 till 2005 and from 2006 till 2010. Although a context of crisis was observed from 2007, this approach will nevertheless enable us to determine if changes of behaviour are observable without attributing them exclusively to the new tax regulation called "notional interests".

This article contains four sections. In the first section, the recent debates on financial theories will be clarified. The influence of family involvement, the size of the company and the system of "notional interests" as explanatory vectors of financial choices will be developed in the second section. The methodology used will be explained in the third section. Finally, the results of our regressions will be presented and discussed in the last section.

\section{Static Trade-off Theory vs Pecking-Order Theory}

The analysis of the financial structure has been lengthily debated in order to understand the financial choices but no consensus can be found. To clarify the differences stated in the literature, this first section proposes an evolutionary logic analysis of the Static Trade-off Theory and the Pecking-Order Theory.

\subsection{From the Fundamentals of Financial Behaviour to the Static Trade-off Theory}

From a historical perspective, the researches of Modigliani and Miller (1958) are considered as the precursors of financial behaviour analysis. Although their first objective was to elaborate principles relative to the evaluation of the firm and risk capital, they revealed the neutrality of financial structure on the firm's value. Indeed, according to Modigliani and Miller (1958), the weighted average cost of capital would be independent of the financial policy adopted by the firm. This assumption implies equivalence of all possible distributions between debts and equity so that the firm's value would not be affected by the financial choices. To that extent, it also seems that investment decisions are independent of the financial structure.

This theory supposed the existence of restrictive hypotheses. Therefore, Modigliani and Miller (1963) change their theory by incorporating the corporate income taxation into their reasoning. Indeed, the deductibility of interest expenses would be a stimulant for the firm to issue more debts. In this way, the firms would rather subscribe to bank or bond loans rather than to issue stocks in order to maximise their valuation. Nevertheless, Modigliani and Miller (1963) were conscious of the limits of this purely arithmetical approach. Indeed, an exaggerated debt issuance policy would reduce firm flexibility. Consequently, they envisaged the existence of an indebtedness target ratio towards which the firms will gravitate. Krauss and Litzenberger (1973) focused on a costs/benefits analysis of debt issuance, elaborating the first reflections on the Static Trade-off Theory. This framework supposes the existence of an indebtedness level maximising firm value. Therefore, interrogations regarding the optimal financial structure are situated in a trade-off perspective between fiscal advantages of debt, costs of financial distress and agency costs (Jensen, 1986; Frank \& Goyal, 2003). Besides, Fama and French (1997) as well as Carpentier and Suret (1999), aware of the deviations between target and real indebtedness ratios, focused on the temporal dimension of financing. These deviations would come from a punctual difference between means and sources of financing. A deviation variable at time «t» was introduced by these authors to catch the difference between target and real indebtedness ratios. The results showed that an underleveraged firm would tend to reach its target ratio more quickly because debt issuance is less sensitive to the problem of information asymmetry than stock issuance. On the other hand, overleveraged firms would reach their target ratio with more difficulty because they would have to issue stocks or use self-financing (Colot \& Croquet, 2007).

The Static Trade-off Theory was subject to empirical researches. Brounen, De Jong and Koedijk (2006) revealed that in the United Kingdom, in the Netherlands and in Germany, more than two thirds of firms would turn to an indebtedness target ratio. The results were more moderate in France where only a third of the firms would gravitate towards such a ratio. Nevertheless, it also seems that $10 \%$ of firms have held strictly to a fixed indebtedness ratio. Flannery and Rangan (2006) showed that nonfinancial companies identify and tend to reach an indebtedness target ratio very quickly for the period 1966-2001. More recently, Nunkoo and Boateng (2010) established that long term leverage of Canadian firms would tend to an indebtedness target ratio event if the adjustment were relatively slow.

\subsection{The Pecking-Order Theory}

Pecking-Order Theory introduces the problem of information asymmetry on financial markets, questioning their 
perfection. Managers would thus have better information than external investors. To correct this, lenders and potential shareholders would demand a premium considered as the cost of information. Consequently, firms would favour self-financing to avoid this premium (Myers \& Majluf, 1984). Besides, Myers and Majluf (1984) also bring a theoretical framework to analyse firms' preferences in terms of external financing. Their framework is based on the assumption that firm's assets are underestimated by potential shareholders. In that case, stock issuance would be done at a lower price so that stock prices would decline on the stock exchange. Firms will thus tend to favour bank and bond debts before issuing new stocks.

Several empirical studies confirm Pecking-Order Theory. Shyam-Sunder and Myers (1999) showed that firms without self-financing means prefer debt issuance to stock issuance. Bharath, Pasquariello and $\mathrm{Wu}$ (2009) studied the relation between the information asymmetry level and the financial structure of firms. The results confirm Pecking-Order Theory since firms with a high level of information asymmetry issue from 40 to $70 \%$ of additional debts compared with those presenting a lower level of information asymmetry. The same study also reveals that firms with a low level of information asymmetry would issue stocks rather than debts. Lemmon and Zender (2006) developed a model taking into account the indebtedness capacity of the firm. This approach integrates an inter-temporal dimension in the Pecking-Order Theory. Indeed, financial choices would depend on the firm's indebtedness capacity which could be currently saved to sustain future financing needs. Results of this research highlight the firm's willingness to finance its projects firstly by itself. Moreover, firms with high indebtedness capacity would prefer debt issuance to stock issuance.

Opposing results show that Pecking-Order Theory can not only explain financial choices by the firm. Frank and Goyal (2003) obtained contrasting results. In an analysis of the American public firms over the period 1971-1998, only large firms follow the Pecking-Order Theory. Fama and French (2005) showed that more than half of the firms quoted on the NYSE, the AMEX and the Nasdaq do not conform to this theory. According to the authors, stock financing can limit transaction costs as well as the problem of information asymmetry. Leary and Roberts (2005) revealed that firms which want to finance large investments tend to issue new stocks while their self-financing capacity seems to be sufficient. This decision could be motivated by the necessity for the firm to find a level of leverage appropriate to its financing preferences.

Besides, Leary and Roberts (2010) also contributed to the debate on Pecking-Order Theory since they obtained divergent results depending on the interpretation of the hypotheses and the empirical models used. This last observation shows the necessity to be cautious when interpreting the results of empirical researches. Moreover, none of the theoretical frameworks developed in this paper can exclusively explain the financial structure of the firm. Consequently, in order to give a relevant analysis, it's necessary to take into account the specificities of the firms and their environment. All these characteristics will be discussed in the next section.

\section{Financial Policy: The Effects of Size, Family Characteristics and Tax Regulation}

The choice of financial policy depends on intrinsic characteristics of the firm (Gallo \& Vilaseca, 1996). Amongst others, size (Rajan \& Zingales, 1995; Gaud \& Elion, 2002; Gatchev, Spindt \& Tarhan, 2009; Leary \& Roberts, 2010) and organizational components (Gallo, 1995; Gallo \& Vilaseca, 1996; DeAngelo \& DeAngelo, 2000; Colot \& Croquet, 2007; Lopez-Gracia \& Sanchez-Andujar, 2007) have an influence on the financial mechanisms adopted by the firm. In this section, an approach in two phases will be implemented, allowing us to analyse clearly the effects of size and family characteristics on the firm's financial policy. Several studies have attempted to understand the relationship between size and financial structure. According to several authors (Rajan \& Zingales, 1995; Gaud \& Elion, 2002; Leary \& Roberts, 2010), size would influence indebtedness positively. Indeed, the impact of activities diversification in large firms would reduce cash flow volatility so that the risk of bankruptcy would be reduced and debt issuance would be stimulated. Johnson (1997) however shows a negative relation between size and bank loans. Carpentier and Suret (1999) also bring results showing a negative effect of size on indebtedness. Gatchev et al. (2009) also confirm these results because size, estimated by the natural logarithm of total assets, would reduce short and medium term debt issuance. Arguments explaining this relation can be found in the information theory which considers size as an inverse indicator of the information level revealed to external investors. Large firms would cope with a bigger problem of information asymmetry with external investors who did not have a sufficient knowledge of the firm's risk level (Halov \& Heider, 2005). As has been shown, theory and a significant empirical contribution indicate a positive effect of size on firm indebtedness but no consensus can be pointed out.

The influence of the type of organisation on financial behaviour receives considerable attention in the literature. Family firms, with their specific characteristics, need to be analysed in depth to understand their financial structure. Indeed, understanding the family business model requires notions of family control and perpetuity 
(Casson, 1999). Family control must be considered according to the family involvement in the shareholding and management of the firm. As soon as the family is dominant in these components, the firm meets the current definitions of a family business (Anderson \& Reeb, 2003; Arrègle, Sirmon, Hitt \& Webb, 2008; Colot, 2010). In such cases, family involvement would stimulate the willingness to ensure perpetuity of activity as well as a more pronounced risk aversion. These components would have an influence on the firms' commitment to risky investments so that a cost would be borne by non-family shareholders (DeAngelo \& Deangelo, 2000). Nevertheless, adopting defensive financial strategies could reduce default risk and loss of control (Hirigoyen, 1982; Ward, 1988). Therefore, we could assume that family firms would try to limit costs of distress by preferring self-financing to debt issuance. On this matter, Gallo and Vilaseca (1996) showed that the ratio «Debts / Stockholders' equity» presented weaker values for family firms. Furthermore, as family businesses want to keep control of the firm, they would develop specific financing preferences when they face a lack of self-financing. In that case, they would issue debt rather than issuing new stocks (Calof, 1985; Colot \& Croquet, 2007). Risk aversion as well as the fear of losing control in family firms would urge them to adopt a hierarchy in their financial choices. The motivations of the family firms to opt for a definite financial structure would thus depend more on the preservation of family control and sustainability of their activity than on a problem of information asymmetry.

However, family firms could also focus on an indebtedness target ratio allowing them to equal the deduction of interest expenses and the costs of financial distress. Besides, family shareholders would maintain their indebtedness level to avoid control expropriation by external investors. In order to test empirically the existence of such a ratio, Lopez-Gracia and Sanchez-Andujar (2007) show that family firms would approach their indebtedness target ratio more quickly than non-family firms.

Moreover, an additional specificity of the Belgian market must be taken into account: the "notional interests" system implemented in 2006 and based on the principle of an allowance for corporate equity. This tax mechanism was conceived to equal the cost of risk capital with the indebtedness cost. It allows the deductibility of fictitious interest expenses on the variation of the corrected equity capital (equity capital - revaluation gains Capital subsidies - Firm's own shares - Other shares in financial assets). The introduction of this tax regulation should induce a growth in equity capital since risk capital deductibility makes it possible to obtain a tax advantage without cash expense and to equal the indebtedness cost with the equity capital cost. Therefore, the "notional interest" system could induce a mutation in the financial choices of the firms.

While Pecking-Order Theory supposed a preference for debt issuance before stock issuance, the tax advantage granted since 2006 reduces the cost of the risk premium demanded by external investors. The trade-off between debt and stock issuance would thus be more complicated for the firms. Besides, Static Trade-off Theory applicability would also be concerned by this new regulation. As risky capital also allows for the deductibility of a tax advantage, the quest for an indebtedness target ratio equalling the costs of financial distress and the interest expenses deductibility (Krauss \& Litzenberger, 1973; Frank \& Goyal, 2003) must be questioned. Indeed, using risk capital would induce, all things being equal, an increase of the financial independence level and thus a decrease in the financial distress costs. Thereby, the "notional interests" mechanism would offer two advantages: the deductibility of a fictitious interest expense as well as a reduction of the financial distress costs. Therefore, financing by using equity capital could become a specific characteristic of financial behaviour on the Belgian markets.

Nonetheless, by positioning in the family firms context, the family managers' willingness to keep control of the business (Hirigoyen, 1982; Ward, 1988) would immediately influence external financing policies so that family firms would prefer debt issuance to stock issuance as mentioned by the Pecking-Order Theory. On the other hand, the introduction of the "notional interests" mechanism could also create a stimulant for equity capital growth as long as stocks are issued for family members or in a proportion which gives the opportunity to family shareholders to keep control of their firm. In the case of public issuance, a new trade-off would thus be made between the costs directly linked with the loss of family members' control and the tax advantage resulting from the deductibility of the "notional interests".

As has been demonstrated during this section, the influence of the family nature of a firm on financial choices is still an underexplored subject with few diversified empirical results. Moreover, the introduction of a specific tax regulation in Belgium creates extra-difficulty in the analysis of financial behaviour. Therefore, the next sections will focus on a comparative approach between family and nonfamily firms to discover whether family character could induce different financial choices. Furthermore, special attention will be devoted to the introduction of a new tax regulation and its influence on the financial behaviour of family and non-family firms. 


\section{Methodology}

\subsection{Model Tested}

In order to identify which theory could explain the financial structure of the large privately-held firms of the Belgian market, our methodology is directly linked with the Shyam-Sunder and Myers (1999) models developed for both Pecking-Order Theory (POT) and the Static Trade-off Theory (STT). They are presented as follows:

$$
\begin{gathered}
\text { POT: } \Delta D_{i t}=a+b_{p o t} D E F_{i t}+e_{i t} \\
\text { STT: } \Delta D_{i t}=a+b_{s t t}\left(D_{i}{ }^{*}-D_{i t-1}\right)+e_{i t}
\end{gathered}
$$

with:

$-\triangle \mathrm{D}$, long-term indebtedness variation after excluding leasing debts;

- DEF, funding deficit of the year (calculation is detailed below);

- $\mathrm{D}_{\mathrm{i}^{*}}$, indebtedness target ratio assessed as the average of long-term indebtedness during the observation period;

- D, long-term indebtedness after excluding leasing debts.

It must be mentioned that every variable is divided by total assets in order to avoid exponential effects in variance calculations.

Funding deficit for year $\mathrm{t}, \mathrm{DEF}_{\mathrm{t}}$, is defined as follows:

$$
D E F_{t}=D I V_{t}+I N V E S T_{t}+\Delta N W C_{t}+R_{t}-C A F_{t}
$$

with:

- DIV $_{\mathrm{t}}$, dividends paid in year $\mathrm{t}$;

- INVEST $t_{t}$, net investment in year $\mathrm{t}$ (sum of investments in intangible, plants, properties, equipment and financial fixed assets in year $t$ - cession of intangible, plants, properties, equipment and financial fixed assets in year $t$ );

- $\Delta \mathrm{NWC}_{\mathrm{t}}$, net working capital variation between year $\mathrm{t}$ and $\mathrm{t}-1$;

- $\mathrm{R}_{\mathrm{t}}$, current portion of long-term debt at start of period excluding leasing debts;

- $\mathrm{CAF}_{\mathrm{t}}$, operating cash-flow after interest and taxes.

The Pecking-Order Theory model supposes that firms will issue debt in the case of a lack of cash to cope with investment expenses, dividend pay-out policy and the funding of their operating cycle. Therefore, parameters expected in equation (1) will be 0 for a and 1 for $b_{\text {pot }}$. Indeed, if $b_{\text {pot }}$ takes the value of 1 , it would mean that the funding deficit is totally covered by the long-term indebtedness variation. Static Trade-off model means that indebtedness variation is explained by an adjustment to an indebtedness target ratio. Therefore, parameters estimated in equation (2) should be 0 for a and a value close to 1 for $b_{\text {stt }}$. If $b_{\text {pot }}$ and $b_{\text {stt }}$ present parameters below the value of 1 , it would mean the existence of adjustment costs (Shyam-Sunder \& Myers, 1999).

\subsection{Target Population}

The building of a sample of 210 privately-held firms was carried out in several steps. Firstly, we collected firms presenting an average number of permanent staff higher than 100 workers. This approach allowed us to comply with the definition of a large company in Belgium.

Secondly, each firm was considered as a family business if it fulfilled the following criteria:

- a family owned at least $50 \%$ of the firm's shares;

- a family has a decisive influence on corporate and transmission strategies. This criterion is fulfilled if management is mainly exercised by a family;

- the majority of the board is composed of family members.

This multi-criteria definition of the family business is regularly used in the literature (Anderson \& Reeb, 2003; Arrègle et al., 2008; Colot, 2010). Each criterion has the particularity of being easily measured. Indeed, the financial database Belfirst (Note 1) is full of information concerning firms' shareholders. Moreover, by using each firm's website, we can check shareholding information collected on Belfirst and obtain other information relative to board and management composition. Besides, our definition of the family firm also takes into account the pyramidal structures which are regularly used in family businesses to maintain their control over a firm without owning the majority of its shares (Laporta, Lopez-De-Silanes \& Shleifer, 1999; Aytac, 2007). Therefore, the use of this selective method determines the real involvement of the family in the firm. 112 family firms have been selected by using these criteria. 
In order to limit demographic biases related to size and sector, non-family firms have been chosen to ensure a comparability balance in our sample. Indeed, as mentioned by Oogheand Van Wymmeersch (2006), financial indicators can be sensitive to economic activities and size. Each non-family firm was thus selected according to the following criteria:

- activity sector: NACEBEL code (Belgian economic activities nomenclature, with 4 figures) identical to family firms;

- size: total assets can vary more than $20 \%$ compared to family firms.

A global sample of 224 family and non-family firms has been collected by using this method. After eliminating public firms as well as the businesses for which information was missing, our sample was reduced to 210 privately-held firms separated into 109 family firms and 101 non-family firms.

\subsection{Statistical Methodology and Tests}

In order to improve the estimations of our parameters we use panel data rather than cross section data. Indeed, as mentioned by Gujarati\& Bernier (2004), that type of data reduces estimations' errors and multicolinearity problems. Moreover, it also allows us to describe individual types of behaviour.

Panel data estimations can be carried out according to Ordinary Least Squares (OLS) or Generalized Least Squares (GLS) with fixed or random effects. Several tests are carried out to determine the model with the best specification. Lagrangian Multiplicator test is used to assess if OLS is enough to specify our model. Hausman test is generated to choose between fixed or random effect regression. For the sake of clarity, our results will be presented with the best regression model for each stage of our research.

\section{Results and Interpretations}

In this section, the results regarding the Pecking-Order and Static Trade-off Theory models are analysed for the entire sample before subsampling between family and non-family firms. After that, we will distinguish two sub-periods: 2002-2005 and 2006-2010. This approach allows us to identify behavioural changes in the financial policy of the firm.

Table 1. Family and non-family firms' financial policy

\begin{tabular}{llllll}
\hline Funding models & Regression type & a & Std deviation (a) & b & Std deviation (b) \\
\hline Pecking-Order Theory & random effect & $0.1086203^{*}$ & 0.0333219 & $-4.106627^{*}$ & 0.0116745 \\
Static Trade-off Theory & fixed effect & $0.0635527^{*}$ & 0.0064531 & $0.7990098^{*}$ & 0.000725 \\
\hline Funding models & Regression type & R squared & F & LM & H \\
\hline Pecking-Order Theory & rando meffect & 0.9835 & $123735.28^{*}$ & 174.53 & 0.4816 \\
Static Trade-off Theory & fixed effect & 0.9975 & $8.43^{*}$ & 1528.76 & $0.016^{*}$ \\
\hline
\end{tabular}

Description: Estimations on panel data for 210 privately held firms on the Belgian market between 2002 and 2010; $a=$ constant, $b=b_{\text {pot }}$ or $b_{\text {stt }}$ according to the funding model considered; F = F-test; R squared = determination coefficient; LM = Lagrangian Multiplicator; $\mathrm{H}=\mathrm{Hausman}$ statistic (prob $>$ chi2).

The results invalidate Pecking-Order Theory. Indeed, while the expected value for $b_{\text {pot }}$ should be situated between 0 and 1 , the estimated $b_{\text {pot }}$ is -4 . Such a result means that the indebtedness variation will decrease in a comprehensive way when funding deficit increases. Firms should thus use other financing means than debt issuance. This orientation towards other financial mechanisms is in accord with the results obtained by Fama and French $(2005)$ as well as Leary and Roberts $(2005,2010)$ who disagree with the financing means hierarchy hypothesis. On the other hand, Static Trade-off Theory is quite well validated since $b_{\text {stt }}$ shows a value close to 0.8 . Besides, we also state that the estimated parameters are individually significant. Furthermore, the determination coefficients present relatively high value even if few variables are used in our models. Therefore, it seems that privately held firms collected in our sample would follow an indebtedness target ratio assessed by the average indebtedness level on the observation period. In order to understand the origins of this statement, we will subsample between family and non-family firms before taking into account the introduction of the new tax regulation concerning equity capital. 
Table 2. Family firms' financial policy

\begin{tabular}{llllll}
\hline Funding models & Regression type & a & Std deviation (a) & b & Std deviation (b) \\
\hline Pecking-OrderTheory & random effect & $0.1012759^{*}$ & 0.0496552 & $-4.144317^{*}$ & 0.0098422 \\
Static Trade-off Theory & random effect & $0.0909954^{*}$ & 0.0300605 & $0.7989008^{*}$ & 0.0009445 \\
\hline Funding models & Regression type & R squared & F & LM & H \\
\hline Pecking-OrderTheory & random effect & 0.9931 & $177306.79^{*}$ & $283.76^{*}$ & 0.8099 \\
Static Trade-off Theory & random effect & 0.998 & $715499.3^{*}$ & $563.71^{*}$ & 0.1398 \\
\hline
\end{tabular}

Description: Estimations on panel data for 109 privately- held family firms on the Belgian market between 2002 and 2010; $a=$ constant, $b=b_{\text {pot }}$ or $\mathrm{b}_{\text {stt }}$ according to the funding model considered; $\mathrm{F}=\mathrm{F}$-test; $\mathrm{R}$ squared = determination coefficient; $\mathrm{LM}=$ Lagrangian Multiplicator; $\mathrm{H}=$ Hausman statistic (prob>chi2).

Estimated coefficients confirm the results obtained for the entire sample. Consequently, family firms would not meet the financing means hierarchy hypothesis but an indebtedness target ratio. Moreover, $b_{\text {pot }}$ and $b_{\text {stt }}$ are individually significant and the $\mathrm{R}$ squared coefficient indicates a strong explicative power for our models. These results corroborate these of Lopez-Gracia and Sanchez-Andujar (2007) which showed that family firms follow an indebtedness target ratio more quickly than nonfamily firms. Following such an indebtedness level can be explained by the willingness of family firms to maintain an indebtedness ratio guaranteeing they can keep family control over the firm (Kenyon-Rouvinez \& Ward, 2004).

Table 3. Non-family firms' financial policy

\begin{tabular}{llllll}
\hline Funding models & Regression type & a & Std deviation (a) & b & Std deviation (b) \\
\hline Pecking-Order Theory & fixed effect & -0.001155 & 0.0024059 & $0.1017165^{*}$ & 0.0104134 \\
Static Trade-off Theory & OLS & 0.0027356 & 0.0024834 & $0.0234653^{*}$ & 0.008183 \\
\hline Funding models & Regression type & R squared & F & LM & H \\
\hline Pecking-Order Theory & fixed effect & 0.0907 & 0.78 & 0 & $0.005^{*}$ \\
Static Trade-off Theory & OLS & 0.009 & $8.22^{*}$ & 0 & 0.8386 \\
\hline
\end{tabular}

Description: Estimations on panel data for 101 privately- held non-family firms on the Belgian market between 2002 and 2010; a = constant, $\mathrm{b}$ $=\mathrm{b}_{\mathrm{pot}}$ or $\mathrm{b}_{\mathrm{st}}$ according to the funding model considered; $\mathrm{F}=\mathrm{F}$-test; $\mathrm{R}$ squared $=$ determination coefficient; $\mathrm{LM}=$ Lagrangian Multiplicator; $\mathrm{H}=$ Hausman statistic (prob>chi2).

The value obtained for each parameter cannot allow us to explain the firm's financial policy by the two main funding models considered in this research. Indeed, $b_{\text {pot }}$ and $b_{\text {stt }}$ present respectively a value of 0.1 and 0.02 although a value of 1 was expected. Moreover, the determination coefficient analysis shows a weak explicative quality for the two models despite the individual significance of the parameters. Thereby, non-family firms' financial policy does not seem to be induced by a hierarchy in the financing means or by the pursuit of an indebtedness target ratio. Nonetheless, indebtedness level stays persistent since the average indebtedness level varies by only $1 \%$ (Note 2 ) during the observation period.

Table 4. Family and non-family firms' financial policy before and after the introduction of an allowance for corporate equity

\begin{tabular}{llllll}
\hline Funding models & Regression type & $\mathbf{a}$ & Std deviation (a) & b & Std deviation (b) \\
\hline Pecking-Order Theory 2002-2005 & fixed effect & -0.0036 & 0.002543 & $0.1168095^{*}$ & 0.0132559 \\
Pecking-Order Theory 2006-2010 & random effect & $0.0939451^{*}$ & 0.039951 & $-4.134226^{*}$ & 0.0115407 \\
\hline Funding models & Regression type & R squared & F & LM & H \\
\hline Pecking-Order Theory 2002-2005 & fixed effect & 0.0911 & 1.13 & 1.04 & $0.0438^{*}$ \\
Pecking-Order Theory 2006-2010 & random effect & 0.991 & $128329.09^{*}$ & $83.97^{*}$ & 0.9958 \\
\hline Funding models & Regression type & $\mathbf{a}$ & Std deviation (a) & $\mathbf{b}$ & Std deviation (b) \\
\hline Static Trade-off Theory 2002-2005 & fixed effect & 0.00542 & 0.002902 & $0.0482593^{*}$ & 0.011352 \\
Static Trade-off Theory 2006-2010 & random effect & $0.0445332^{*}$ & 0.009543 & $0.7996687^{*}$ & 0.0003623 \\
\hline Funding models & Regression type & R squared & F & LM & H \\
\hline Static Trade-off Theory 2002-2005 & fixed effect & 0.0023 & 1.15 & 0.26 & $0.0001^{*}$ \\
Static Trade-off Theory 2006-2010 & random effect & 0.9997 & $4870000^{*}$ & $432.79^{*}$ & 0.0692 \\
\hline
\end{tabular}

Description: Estimations on panel data for 210 privately held firms on the Belgian market for the periods 2002-2005 and 2006-2010; $\mathrm{a}=$ constant, $\mathrm{b}=\mathrm{b}_{\mathrm{pot}}$ or $\mathrm{b}_{\mathrm{stt}}$ according to the funding model considered; $\mathrm{F}=\mathrm{F}$-test; $\mathrm{R}$ squared $=$ determination coefficient; $\mathrm{LM}=\mathrm{Lagrangian}$ Multiplicator; $\mathrm{H}=$ Hausman statistic (prob $>$ chi2). 
The results indicate a change in the behaviour of the firms from the introduction of "the notional interests" regulation. Indeed, even if the parameters are significant for the period 2002-2005, determination coefficients are too weak to validate the explicative property of Pecking-Order or static Trade-off Theory models. Furthermore, the estimations of parameters are also too weak to validate a link with a particular theory.

A trend seems to appear for the period 2006-2010 where the determination coefficients as well as all individual parameters suggest a better statistical significance. In terms of financial behaviour, we observe a strongly negative influence of the funding deficit on the indebtedness level for the period 2006-2010. Therefore, the only available resource to finance deficit funding is stock issuance. These results are in conflict with those supporting Pecking-Order Theory according to which the hierarchy in financing means would induce a preference for debt issuance before stock issuance. The value of $b_{\text {stt }}$ (close to 0.8) corroborates the pursuit of an indebtedness target ratio proposed by the Static Trade-off Theory. The origin of this situation would come from a downward adjustment of the indebtedness ratio since the average variation of this ratio is -0.31263773 (Note 2) during the period 2006-2010. In order to catch a behavioural difference between family and non-family firms, we will subsample between these two types of organization.

Table 5. Family firms' financial policy before and after the introduction of the «notional interest» regulation

\begin{tabular}{llllll}
\hline Funding models & Regression type & a & Std deviation (a) & b & Std deviation (b) \\
\hline Pecking-Order Theory 2002-2005 & OLS & -0.006 & 0.003261 & $0.0680691^{*}$ & 0.017154 \\
Pecking-Order Theory 2006-2010 & random effect & 0.10321 & 0.061137 & $-4.152522^{*}$ & 0.010276 \\
\hline Funding models & Regression type & R squared & F & LM & H \\
\hline Pecking-Order Theory 2002-2005 & OLS & 0.035 & $15.75^{*}$ & 0 & 0.3972 \\
Pecking-Order Theory 2006-2010 & random effect & 0.9957 & $163283^{*}$ & $125.59^{*}$ & 0.8468 \\
\hline Funding models & Regression type & $\mathbf{a}$ & Std deviation (a) & $\mathbf{b}$ & Std deviation (b) \\
\hline Static Trade-off Theory 2002-2005 & OLS & -0.0037 & 0.003357 & 0.0036094 & 0.003879 \\
Static Trade-off Theory 2006-2010 & random effect & $0.0554052^{*}$ & 0.010222 & $0.7997082^{*}$ & 0.000334 \\
\hline Funding models & Regression type & R squared & F & LM & H \\
\hline Static Trade-off Theory 2002-2005 & OLS & 0.002 & 0.87 & 0 & 0.0738 \\
Static Trade-off Theory 2006-2010 & random effect & 0.9999 & $5730000^{*}$ & $123.94 *$ & 0.0613 \\
\hline
\end{tabular}

Description: Estimations on panel data for 109 privately- held family firms on the Belgian market for the periods 2002-2005 and 2006-2010; a $=$ constant, $\mathrm{b}=\mathrm{b}_{\text {pot }}$ or $\mathrm{b}_{\text {stt }}$ according to the funding model considered; $\mathrm{F}=\mathrm{F}$-test; $\mathrm{R}$ squared $=$ determination coefficient; $\mathrm{LM}=\mathrm{Lagrangian}$ Multiplicator; $\mathrm{H}=$ Hausman statistic (prob $>$ chi2).

The results confirm the observations made for the entire sample. We can observe that the pursuit of an indebtedness target ratio and the use of stock issuance are two special features in family firms' financial behaviour. Such a situation is in conflict with the research of Colotand Croquet (2007) concerning the SMEs of the Belgian market. Indeed, they found that family business prefer debt issuance rather than stock issuance. Therefore, we can state the family firms' willingness to minimize their financial distress costs (Krauss \& Litzenberger, 1973) and to maximize their tax benefits coming from the new tax regulation.

Table 6. Non-family firms' financial policy before and after the introduction of the «notional interest» regulation

\begin{tabular}{llllll}
\hline Funding models & Regression type & $\mathbf{a}$ & Std deviation (a) & b & Std deviation (b) \\
\hline Pecking-Order Theory 2002-2005 & random effect & 0.00026 & 0.004445 & $0.1202424^{*}$ & 0.014647 \\
Pecking-Order Theory 2006-2010 & random effect & -0.002 & 0.003102 & $0.0603482^{*}$ & 0.011739 \\
\hline Funding models & Regression type & R squared & F & LM & H \\
\hline Pecking-Order Theory 2002-2005 & random effect & 0.1371 & 67.39 & $3.53^{*}$ & 0.1289 \\
Pecking-Order Theory 2006-2010 & random effect & 0.0472 & 26.43 & $3.24^{*}$ & 0.1855 \\
\hline Funding models & Regression type & $\mathbf{a}$ & Std deviation (a) & $\mathbf{b}$ & Std deviation (b) \\
\hline Static Trade-off Theory 2002-2005 & fixed effect & 0.00623 & 0.005417 & $0.0351378^{*}$ & 0.015436 \\
Static Trade-off Theory 2006-2010 & fixed effect & -0.0049 & 0.002845 & -0.1006685 & 0.02066 \\
\hline Funding models & Regression type & R squared & F & LM & H \\
\hline Static Trade-off Theory 2002-2005 & fixed effect & 0.0032 & $3.54^{*}$ & 1.67 & $0 *$ \\
Static Trade-off Theory 2006-2010 & fixed effect & 0.0218 & $1.42^{*}$ & 0 & $0 *$ \\
\hline
\end{tabular}

Description: Estimations on panel data for 101 nonfamily privately held firms on the Belgian market for the periods 2002-2005 and 2006-2010; $\mathrm{a}=$ constant, $\mathrm{b}=\mathrm{b}_{\text {pot }}$ or $\mathrm{b}_{\text {stt }}$ according to the funding model considered; $\mathrm{F}=\mathrm{F}$-test; $\mathrm{R}$ squared $=$ determination coefficient; $\mathrm{LM}=\mathrm{Lagrangian}$ Multiplicator; $\mathrm{H}=$ Hausman statistic (prob>chi2). 
As has already been stated in the first part of our paper, estimators do not allow us to establish a link with the two theories considered. Indeed, despite the individual significance of the parameters, the determination coefficients indicate a weak explicative property of the regressed models. This situation could be explained by the static character of the non-family firms' financial structure since their indebtedness level seems to remain the same during the two periods (Note 2). Therefore, no changes appear in the financial behaviour of non-family firms.

\section{Conclusion}

The aim of this paper was to distinguish the financial behaviour adopted by family firms in comparison with non-family firms in an environment where tax regulation can influence the financing costs of equity capital. The literature review showed how little attention had been paid to family firms in terms of financial behaviour. Furthermore, the main researches focused on family SMEs (Colot \& Croquet, 2007; Lopez-Gracia \& Sanchez-Andujar, 2007).

The analysis of our results demonstrates a divergence between family and non-family firms. Nevertheless, this situation must be appreciated for the period 2006-2010 since no significant evidence regarding a behavioural dissimilarity was found for the previous period 2002-2005. While family firms seem to pursue an indebtedness target ratio and to finance their funding deficit by issuing stocks, non-family firms follow none of the theories considered in our research. Hence, the financial policies adopted by family firms shift towards a reduction of their indebtedness level and an increase of their financial independence level. Such a situation allows them to limit their financial distress costs (Frank \& Goyal, 2003) and to benefit from a tax advantage owing to the deductibility of a fictitious and undisbursed interest expense. The double benefit resulting from the coming into force of the new tax regulation could thus exercise an effect on the financial behaviour adopted by family firms. Nonetheless, we cannot draw a robust conclusion as the observation period 2006-2010 was perturbed by the consequences of the financial and economic crisis. In such a context, it would be inappropriate to attribute financial behaviour modifications observed by family firms only to changes in taxation regulation.

The impossibility of determining the real effect of the new tax regulation on financial habits is a limit on our research as well as a future field for investigation. Indeed, the motivations having induced a deleveraging in family businesses could find their origins in the willingness to minimise taxation. Besides, growth in financial independence could also find an interpretation in the family firms' willingness to minimise their financial distress costs allowing them to perpetuate their activities in a period of economic contraction (Ward, 1988; Kenyon-Rouvinez \& Ward, 2004).

This paper contributes to literature on several ways. First, it highlights the influence of Static Trade-off Theory on family firms' financial behaviour while few researches have been carried out in this area. Besides, it launches a debate regarding the effect of the introduction of an allowance for corporate equity on firms' financial habits. Finally, it also contributes to new research perspectives such as a comparative analysis between other European states where a "notional interests" system or analogue mechanisms do not exist. This approach could limit the effects of the financial and economic crisis so that it would be possible to isolate the influence of family characteristics on the financial structure of the firm.

\section{References}

Anderson, R., \& Reeb, D. (2003). Founding family ownership and firm performance: evidence from the S\&P 500. The Journal of Finance, 58(3), 1301-1327. http://dx.doi.org/10.1111/1540-6261.00567

Arrègle, J. L., Sirmon, D. G., Hitt, M. A., \& Webb, J. W. (2008). The Role of Family Influence in Firms' Strategic Responses to Threat of Imitation. EntrepreneurshipTheory and Practice, 32(6), 979-998. http://dx.doi.org/10.1111/j.1540-6520.2008.00267.x

Aytac, B. (2007). L'affiliation à une structure pyramidale implique-t-elle des différences conséquentes quant à la structure des entreprises turques? from http://affi2007.u-bordeaux4.fr/Actes/128.pdf.

Bharat, S. T., Pasquariello, P., \& Wu, G. (2009). Does asymmetric information drive capital structure decisions? Review of Financial Studies, 22(8), 3211-3243. http://dx.doi.org/10.1093/rfs/hhn076

Brounen, D., De Jong, A., \& Koedijk, K. (2006). Capital structure policies in Europe: Survey evidence. Journal of Banking and Finance, 30(5), 1409-1442. http://dx.doi.org/10.1016/j.jbankfin.2005.02.010

Calof, J. (1985). Analysis of small business owners financial preferences. Journal of Small Business and Entrepreneurship, 3(3), 39-44.

Carpentier, C., \& Suret, J. M. (1999). Stratégies de financement des entreprises françaises: une analyse 
empirique. SérieScientifique (CIRANO), 99s-09, 1-33.

Casson, M. (1999). The economics of the family firm. Scandinavian Economic History Review, 47, 10-23. http://dx.doi.org/10.1080/03585522.1999.10419802

Colot, O. (2010). La performance de la Transmission des entreprises familiales. Editions Universitaires Européennes, Bruxelles.

Colot, O., \& Croquet, M. (2007). L'endettement des moyennes entreprises familiales est-il différent de celui des moyennes entreprises non familiales ? Le cas de la Belgique. Management et Avenir, 11, 167-185. http://dx.doi.org/10.3917/mav.011.0167

DeAngelo, H., \& DeAngelo, L. (2000). Controlling shareholders and the disciplinary role of corporate payout policy. Journal of Financial Economics, 56, 153-207. http://dx.doi.org/10.1016/S0304-405X(00)00039-8

Duh, M., Tominc, P., \& Rebernik, M. (2009). The Importance of Family Enterprises in Transition Economies: Is $\begin{array}{llll}\text { It Overestimated? Eastern } & \text { European }\end{array}$ http://dx.doi.org/10.2753/EEE0012-8775470602

Fama, E. F., \& French, K. R. (2005). Financing decisions: who issues stock? Journal of Financial Economics, 76, 549-582. http://dx.doi.org/10.1016/j.jfineco.2004.10.003

Flannery, M. J., \& Rangan, K. P. (2006). Partial adjustment toward target capital structures. Journal of Financial Economics, 79(3), 469-506. http://dx.doi.org/10.1016/j.jfineco.2005.03.004

Frank, M., \& Goyal, V. (2003). Testing the pecking order theory of capital structure. Journal of Financial Economics, 67, 217-248. http://dx.doi.org/10.1016/S0304-405X(02)00252-0

Gallo, M. (1995). The role of family business and its distinctive characteristic behavior in industrial activity. Family Business Review, 8(2), 83-98. http://dx.doi.org/10.1111/j.1741-6248.1995.00083.x

Gallo, M., \& Vilaseca, A. (1996). Finance in family business. Family Business Review, 9(4), 387-405. http://dx.doi.org/10.1111/j.1741-6248.1996.00387.x

Gatchev, V. A., Spindt, P. A., \& Tarhan, V. (2009). How do firms finance their investments? The relative importance of equity issuance and debt contracting costs. Journal of Corporate Finance, 15(2), 179-195. http://dx.doi.org/10.1016/j.jcorpfin.2008.11.001

Gaud, P., \& Elion, J. (2002). Déterminants et dynamique de la structure du capital des entreprises suisses: une étude empirique. Cahiers de recherche-HEC Genève, 12, 32.

Gujarati, D., \& Barnier, B. (2004). Économétrie. Éditions De Boeck, Bruxelles.

Halov, N., \& Heider, F. (2005). Capital structure, risk, and asymmetric information. EFA 2004 Maastricht, 1-36.

Hirigoyen, G. (1982). Le comportement financier des moyennes entreprises industrielles familiales. Banques, 417, 588-593.

Ifera. (2003). Family business dominate. Family Business Review, 16(4), 235-239.

Jensen, M. (1986). Agency costs of free cash-flow, corporate finance, and takeovers. The American Economic Review, 76, 323-329.

Johnson, S. A. (1997). An empirical analysis of the determinants of corporate debt ownership structure. European Economic Review, 44, 281-304.

Kenyon-Rouvinez, D., \& Ward, J. L. (2004). Les entreprises familiales. Paris: Presse Universitaire de France.

Krauss, A., \& Litzenberger, R. H. (1973). A state-preference model of optimal financial leverage. Journal of Finance, 28, 911-922. http://dx.doi.org/10.1111/j.1540-6261.1973.tb01415.x

Laporta, R., Lopez-De-Silanes, R., \& Shleifer, A. (1999). Corporate ownership around the world. Journal of Finance, 54(2), 471-517. http://dx.doi.org/10.1111/0022-1082.00115

Leary, M. T., \& Roberts, M. R. (2005). Do Firms Rebalance Their Capital Structures? The Journal of Finance, 60(6), 2575-2619. http://dx.doi.org/10.1111/j.1540-6261.2005.00811.x

Leary, M. T., \& Roberts, M. R. (2010). The pecking order, debt capacity and information asymmetry. Journal of Financial Economics, 95, 332-355. http://dx.doi.org/10.1016/j.jfineco.2009.10.009

Lemmon, M. L., \& Zender, J. F. (2006). Debt capacity and test of capital structure theories. Journal of Financial and Quantitative Analysis, 1-49. 
Lopez-Gracia, J., \& Sanchez-Andujar, S. (2007). Financial structure of the family business: Evidence from a group of small Spanish firms. Family Business Review, 20(4), 269-287. http://dx.doi.org/10.1111/j.1741-6248.2007.00094.x

McCann, G., Demoss, M., Dascher, P., \& Barnett, S. (2003). Educational needs of family businesses: Perceptions of University Directors. Family Business Review, 16(4), 283-291.

Modigliani, F., \& Miller, M. (1958). The cost of capital, corporation finance and the theory investment. The American Economic Review, 58(3), 261-297.

Modigliani, F., \& Miller, M. (1963). Corporate income taxes and the cost of capital: a correction. The American Economic Review, 53, 433-443.

Myers, S. C., \& Majluf, N. S. (1984). Corporate financing and investment decisions when firms have information that investors do not have. Journal of Financial Economics, 13, 187-221. http://dx.doi.org/10.1016/0304-405X(84)90023-0

Nunkoo, P. K., \& Boateng, A. (2010). The empirical determinants of target capital structure and adjustment to long-run target: evidence from Canadian firms. AppliedEconomicsletters, 17(10), 983-990. http://dx.doi.org/10.1080/17446540802599671

Ooghe, H., \& Van Wymeersch, C. (2006). Traité d'analyse financière. Arthémis, Bruxelles.

Rajan, G. R., \& Zingales, L. (1995). What do we know about capital structure? Some evidence from international data. The Journal of Finance, 50(6), 1421-1460. http://dx.doi.org/10.1111/j.1540-6261.1995.tb05184.x

Shyam-under, L., \& Myers, S. C. (1999). Testing static trade off against pecking order models of capital structure. Journal of Financial Economics, 51, 219-244.

Ward, J. (1988). The special role of strategic planning for family business. Family Business Review, 1(2), 105-117. http://dx.doi.org/10.1111/j.1741-6248.1988.00105.x

\section{Notes}

Note 1. Belfirst contains all annual financial statements of Belgian firms which are subject to the legal obligation to publish these financial statements.

Note 2. See appendix 1: Average variations of the indebtedness level.

\section{Appendix}

Appendix 1. Average variations of the indebtedness level

\begin{tabular}{lll}
\hline & Observation periods & Average variations of the indebtedness level \\
\hline Entire sample & $2002-2010$ & -0.173630894 \\
& $2002-2005$ & 0.000127646 \\
& $2006-2010$ & -0.312637726 \\
\hline Family firms & $2002-2010$ & -0.336180048 \\
& $2002-2005$ & -0.004294344 \\
\hline Non-family firms & $2006-2010$ & -0.601688612 \\
& $2002-2010$ & 0.00179344 \\
& $2002-2005$ & 0.004899892 \\
\hline
\end{tabular}

Description: This table provides the average variations of indebtedness level annual differences for the entire sample of 210 firms as well as for the 109 family firms and 101 non family firms. 